\title{
Histopathological Biomarkers as Indicators of the Environmental Quality of Two Estuaries in Northeastern Brazil
}

ITALA Gabriela Sobral SANTOS ( $\square$ italagsobral@hotmail.com )

UFRPE: Universidade Federal Rural de Pernambuco https://orcid.org/0000-0003-3952-9799

Alex Souza Lira

Universidade Federal do Delta do Parnaiba

Carolina da Silva Montes

Universidade Federal do Pará: Universidade Federal do Para

Flávia Lucena Frédou

Universidade Federal Rural de Pernambuco

Rossineide Martins Rocha

Universidade Federal do Pará: Universidade Federal do Para

\section{Research Article}

Keywords: gill, liver, biomarkers, histology, anthropic impacts, Brazilian coast

Posted Date: December 2nd, 2021

DOI: https://doi.org/10.21203/rs.3.rs-1081992/v1

License: (9) This work is licensed under a Creative Commons Attribution 4.0 International License. Read Full License 


\section{Abstract}

The present study aimed at evaluating the environment quality of the Santa Cruz Channel estuary (area 1) and Sirinhaém river estuary (area 2), Northeastern Brazil, using histopathological biomarkers of liver and gills of fish species with different trophic levels as indicators. It was collected liver and gills from five species: Bairdiella ronchus $(\mathrm{n}=24)$ and Gobionellus stomatus $(\mathrm{n}=34)$ in the area 1 ; Caranx latus $(\mathrm{n}=35)$, Centropomus undecimalis $(n=24)$ and Centropomus parallelus $(n=29)$ from area 2 . The liver showed several damages, such as, hepatic steatosis, necrosis, vacuolar degeneration, and infiltration.

Centropomus undecimalis had the highest Histopathological Index of Liver (HIL). Gills exhibited moderate to severe alterations for all species, such as the lifting of epithelial cells, lamellar aneurysm, and rupture of the lamellar epithelium. Centropomus undecimalis in area 2 and G. stomatus in area 1 had the higher number of alterations in their organs. Both areas have been historically affected by mercury $(\mathrm{Hg})$ pollution in área 1 and by the sugarcane industry in area 2 and the species used as biomarkers has been proven to be severely damaged in both estuaries. Species chosen in this study were considered good bioindicators of pollution and the combination of biomarkers methodologies in two organs, pioneering in the Northeastern of Brazil, was efficient in diagnosing the health status of the area using fish as bioindicator.

\section{Introduction}

Estuaries are transitional ecosystems characterized by ecological cycles that receive high inputs of organic and inorganic contaminants, such as pesticides and heavy metals (Salas et al. 2017) from the multiple coastal anthropogenic activities, which negatively affects the health of humans and biota (Dellamatrice and Monteiro 2014; Carr et al. 2017). These contaminants are discharged into the water and accumulate mainly in the sediment (Kameli et al. 2017; Willacker et al. 2017).

Discharges of domestic, industrial and agriculture effluents are among the activities with the greatest potential for contamination in tropical coastal ecosystems (Saldarriaga-Hernandez et al. 2020). The first challenge is to identify chemicals that potentially present a risk to resident fish (Naidu et al. 2016). Industrial activities are responsible for many impacts and the discharge of heavy metal, has become a worldwide concern (Boran and Altinok 2010; Ali et al. 2019). Industries of leather tanning, production of cement, chlor-alkali, mining, anticorrosive agent, and fertilizer production (Pacyna et al. 2010; Cipurkovic et al. 2014; Aslam and Yousafzai 2017; Becker et al. 2018; Chellaiah 2018; Vieira et al. 2019) are among the main industrial activities that threaten the balance of ecosystems. Pollutants, such as pesticides and herbicides, used in the cultivation of sugar cane, are also of great concern given their impact on estuaries, consequently on biota (Chavan and Muley 2014; Coelho et al. 2018).

Fish are considered good indicators for assessing the quality of aquatic environments since they bioconcentrate and bioaccumulate contaminants by direct absorption from water or indirectly by consumption of contaminated prey(Kroon et al. 2017), consequently reaching the upper trophic levels (Wang 2002). The choice of species to be used as an indicator of contamination is essential (Van der 
Oost et al. 2003), and those from different trophic guilds and with distinct trophic position are recommended because they use different absorption/accumulation routes, directly related to the type of food consumed (Terra et al. 2008).

Histopathological biomarkers are widely applied to investigate the effects of contamination on organisms, due to the possibility of identifying lesions in cells, tissues, and organs (Hook et al. 2014; Van der Oost et al. 2003; Viana et al. 2013). The mechanism to evaluate this biomarker is through histopathological changes in the tissue, as it is a direct response of sublethal effects, allowing the detection of the effect of pathogens in an efficient and easy-to-apply manner (Bernet et al. 1999; Fonseca et al. 2016). Among the organs, the liver is often used since it is essential for the physiological functioning of the animal, by detoxifying and excreting toxic substances, and bioaccumulate pollutants (Borges et al. 2018). Gills, owning to their fundamental role in gas exchange and osmotic regulation in fishes, are similarly recommended for environmental biomonitoring(Ameur et al. 2015). This approach is widespread used to assess water quality in polluted environments (Dalzochio et al. 2016).

In this study, for the first time in northeastern of Brazil, we evaluate the environment quality of the Santa Cruz Channel estuary (area 1) and Sirinhaém river estuary (area 2) using liver and gills as histopathological biomarkers for fishes from different trophic levels. These areas are strongly impacted by the intense domestic and industrial effluent discharge, shrimp farming, and artisanal fishing (Medeiros et al. 2001; David and Fontanetti 2009; Moura and Candeias 2009).

\section{Materials And Methods}

\subsection{Study area}

The study area includes two estuarine systems, positioned along the coast of Pernambuco state, northeastern Brazil (Fig. 1). The Santa Cruz Channel Estuary (SCC, area 1) is the largest and highly productive estuary in Pernambuco coast (Macêdo et al. 2000) (Fig 1a). It is a 22 km long U-shaped channel with width ranging from 0.6 to $1.5 \mathrm{~km}$, located within the Santa Cruz Environmental Preservation Area (APA Santa Cruz). A chloro-alkali industry was responsible for launching 22 to 35 tons of inorganic mercury in an important effluent of the SCC complex for approximately 24 years of operation (Meyer 1996). These impacts may have contributed for the reduction of up $10 \%$ of mangrove coverage in this area (Pelage et al. 2019).

The Sirinhaém River Estuary (SIR, area 2) is a small, shallow, coastal plain estuary, $9.5 \mathrm{~km}$ long, $350 \mathrm{~m}$ wide increasing up to $800 \mathrm{~m}$ at the river's mouth and with maximum depth ranging from 1.2 to 4.5 $\mathrm{m}$ (Silva et al. 2011). Located between the Marine Protected Area of Guadalupe and the Marine Protected Area of Sirinhaém, SIR is characterized by a high density of mangrove, occupying $18 \mathrm{~km}^{2}$ (Maia et al. 2006) (Fig. 1b). Although it is of extreme biological importance, multiple impacts are reported in the SIR estuary such as the sugar cane and domestic and industry effluent (CPRH 2011).

\subsection{Fish samples}


In both estuaries, fishes were collected using block nets set close to mangrove creeks $(350 \times 2.9 \mathrm{~m}$, mesh $70 \mathrm{~mm}$ ) and beach seine trawls (20×1.9 m, mesh $20 \mathrm{~mm})$, during 2018 and 2019. The fish species were chosen considering their importance for the local community as a source of food and income, and also the different trophic guilds. The trophic guild of each species was classified according to Elliott et al. (2007) and Mourão et al. (2014) as Detritivore (DV), Piscivore/Zoobenthivore (PVZB) and Piscivore (PV). Bairdiella ronchus $(n=24, P V)$ and Gobionellus stomatus $(n=34, D V)$ were sampled in area 1 and Caranx latus $(n=35, P V Z B)$, Centropomus undecimalis $(n=24, P V)$ and C. parallelus $(n=29, P V Z B)$ were collected from area 2.

Since the fish sampled material arrived dead on board, the Brazilian animal ethics committee wasn't required given that any method of sacrifice inside the authorized fishery activity wasn't demanded, therefore their approval wasn't needed. All specimens were stored on ice and transported to the laboratory. In the laboratory, all fishes were measured (Standard Length $-\mathrm{cm}$ ) and weighed $(\mathrm{g})$. Posteriorly, an abdominal incision was made to assess the liver.

\subsection{Histology}

The liver was weighted, and the median portion of this organ and the second branchial arch right were removed. Subsequently the collected tissues were fixed in 10\% formalin for 24 hours and then preserved in $70 \%$ ethanol for histopathological analysis and subjected to routine histological processing for paraffin embedding (Prophet et al. 1995). Samples were subsequently sectioned into 5 - $\mu$ m-thick sections using a RM2245 microtome (Leica Microsystems, Germany). The liver was stained with hematoxylin and eosin $(\mathrm{HE})$, hematoxylin and eosin-phloxine B (HE-P), Mallory Trichrome. The gills were stained with (HE) and (HE-P). Stained sections were analyzed, and photomicrographs were obtained using an Eclipse Ci-S light microscope (Nikon, Japan) connected to a Nikon DS-Ri1 digital camera.

\subsection{Histopathological indicators}

\subsubsection{Histopathological Index of the liver (HIL)}

Liver changes were semi-quantitatively assessed according to the adapted protocol described by Bernet et al. (1999). The Histopathological Index of the Liver (HIL) was calculated for everyone by multiplying the importance factor by the occurrence value of each alteration (see Table 1-List of alterations). According to this index, Bernet et al. (1999) an occurrence value was attributed to each change by taking into consideration the following tissue injury levels: (1) minimum - easily reversible change; (2) moderate - reversible if the stressor is neutralized; and (3) severe - often irreversible, thus leading to decreased liver function. It was possible to assign an occurrence value to the changes after they were identified. This value corresponds to the level and extent of the tissue changes, namely: (0) unchanged; (2) occasional; (4) moderate and (6) severe (diffuse lesion).

High HIL values indicate more severe injuries in the affected organs. These indices are indicative of the extent and intensity of histological alterations in tissue morphology expressed into a quantitative value. 
Because of this, the method recommends to use the frequency of the histological alterations, calculated from the occurrence of an alteration divided by the total HIL of the sample and multiplied by 100 , in all analyzed fish and for each site.

The Hepatosomatic Index (HSI) (Eq.1) (Slooff et al. 1983) and Condition Factor (K)(Eq.2) (Smolders et al. 2002) were also used to assess the status of the fish health, since the variation in the weight of the organ in relation to body weight is a response of the individual when exposed to contaminants (da Mata Pavione et al. 2019). The HSI was calculated as:

$$
H S I=100 \times \frac{\text { liver weight }(\mathbf{g})}{\text { body weight }(\mathbf{g})}
$$

While the condition factor calculated by Eq. 2:

$$
K=100 \times \frac{W}{L^{3}}
$$

Where $\mathrm{W}=$ body weight $(\mathrm{g})$ and $\mathrm{L}=$ total length of fish $(\mathrm{cm})$.

\subsubsection{Fish health Index (FHI)}

The Fish Histopathological Index (FHI) (Zimmerli et al. 2007) (was used to classify liver injury severity. This index is divided into five classes as follows: Class I $(<10)$, normal/healthy tissue structure without impairments or pathological alterations; Class II (11 - 20), normal tissue structure with slight histological alterations; Class III (21 - 30), moderate modifications of normal tissue and morphology; Class IV (31 40 ), pronounced histological changes (in the liver); and Class V (>40), severe histological alterations of normal tissue and morphology.

\subsubsection{Histopathological Index of the gill (HIG)}

The gill histopathological alterations were calculated from the adaptation of the Poleksic and MitrovicTutundzic (1994) classification. The type and location of the damaged gill tissue are divided into five groups: $a$. hypertrophy and hyperplasia of gill epithelia and related changes; $b$. changes in the mucous cells; $c$. gill parasites; $d$. blood vessel changes and $e$. last terminal stages. After that, the method determined stage of each group of alteration (Table 1), The HIG was calculated as Eq.3:

$$
H I G=\sum I+\left(10 \times \sum I I\right)+(100 \times \Sigma I I I)(3)
$$

Where I, II, and III are the number of stages for lesions. An overall score is used to classify the organ 0-10: functioning normally, 11-20: slightly to moderately damaged, 21-50: moderately to heavily damaged and $>100$ irreparably damaged.

\subsection{Statistical analysis}


Firstly, the normality and homoscedasticity for HIL and HIG data were tested using Shapiro and Bartlett tests respectively. However, the assumptions of parametric tests were not reached, hence the KruskalWallis non-parametric test, followed by Nemenyi test for multiples comparisons (post-hoc) was performed to compare, the HIL and HIG values difference between species, guild and site. In addition, for comparisons between the lesion classes HIL (4 stages) and HIG (3 stages)_for each species.

To assess the degree of resemblance in the histopathological alterations among species for liver and gills, multidimensional scaling (MDS) based on a Euclidian distances matrix was applied using the frequency of occurrence of histopathological alterations (\%) as input, with the specimens considered as the sampling unit. Wisconsin double standardization was applied to improve the gradient detection ability of the dissimilarity indices (Bray et al. 1957). To compare the whole set of histopathological alterations among sites and fish species, a two-way PERMANOVA was applied (Wang et al. 2009). All analyses were performed in the R environment (Core Team R 2020), using vegan (Oksanen et al. 2017) and rrcov packages (Todorov and Filzmoser 2009). For all analyses, a significance level of $0.05 \%$ was considered.

\section{Results}

\subsection{Fish analysis}

A total of 146 individuals were analyzed. Gobionellus stomatus (3.82) and Bairdiella ronchus (1.13) in Santa Cruz Channel Estuary had the highest HSI (Table 2). In terms of condition factor (CF), the highest values were observed in Caranx latus (2.68) and B. ronchus (1.97), and the lowest in G. stomatus (1.01).

\subsection{Histopathology of liver}

We observed 13 types of alterations in the liver distributed in the classes: circulatory (1), inflammatory (3), progressive (1) and regressive (8), summarized by the Histopathological Index of Liver (HIL - Fig. 2). These alterations are divided into four categories given the reaction pattern, such as (1) circulatory disturbances (pathological condition of blood and tissue flow), including hemorrhage and aneurysm, (2) regressive changes (causes reduction or loss or the organ function) which involve cytoplasm alteration, hepatic steatosis, hepatic parenchyma, necrosis, nuclear alterations, and vacuolar degeneration, (3) progressive changes (increased activity of cells or tissues) represented by hypertrophy and hyperplasia in hepatic parenchyma and (4) inflammation (consequence of other reaction patterns) such as infiltration and parasites. The more relevant alterations are regressive changes. Six alterations were the most representative: hemorrhage $(97.26 \%)$, structural alterations in liver tissue $(100 \%)$, steatosis hepatic (92.46\%), necrosis (72.60\%), vacuolar degeneration (95.89\%), and infiltration (94.52\%). All studied fish species showed these changes but with different magnitudes.

Considering the areas, area 1 was significant different to area 2, and $C$. undecimalis in area 2 and $G$. stomatus in area 1 had the most severe changes. The HIL index of G. stomatus in area 1 were significant higher $(66.47 \pm 3.32)$ than those observed in B. ronchus (55.21 \pm 5.85$)$ (Fig. 2- HIL total). In area 2, the HIL 
was significantly different between species $C$. undecimalis $(67.08 \pm 5.97), C$. latus $(45.4 \pm 3.44)$ and $C$. parallelus (52.10 \pm 4.26$)$. Based on Fish Health Index (FHI), all species were considered with severe alterations given the morphology and hepatic parenchyma.

The rank of the histopathological index of liver (HIL), in severity order, was Centropomus undecimalis > Gobionellus stomatus $>$ Bairdiella ronchus $>$ Centropomus parallelus $>$ Caranx latus. Although $C$. undecimalis and G. stomatus are more impacted in absolute values of HIL, G. stomatus had severe histological changes, such as fatty degeneration. In relation to the trophic guild, HIL values were significant different between piscivore and piscivore/zoobenthivore, respectively $C$. undecimalis and $C$. latus, and detritivore versus piscivore/zoobenthivore, corresponding to $G$. stomatus and $C$. latus. In general, piscivores ( $C$. undecimalis and B. ronchus) and detritivores ( $G$. stomatus) were more affected by local contamination.

In the MDS plot based on liver alterations, it is possible to observe a clear separation of G. stomatus from the other species (Fig. 3a). There were significant alterations in the whole histopathological alterations between $G$. stomatus and other species (pseudo-F $=9.89 ; p<0.001$ ), and there was difference between areas (pseudo-F $=21.84 ; p<0.001$ ), mainly due to the high occurrence of four changes (Fig. $3 b$ ), the vacuolar degeneration (Fig.4g), architectural and structural alteration, hyperplasia, and hepatic steatosis, in comparison with the other species. It was observed a high frequency of some alterations by species: such as necrosis in $C$. undecimalis (Fig. 4e), inflammation by leukocyte infiltrate in $C$. latus (Fig. $4 \mathrm{~d}$ ) and parasites in $B$. ronchus.

Hepatic steatosis (Fig. 4b-c) was noted with a varying degree of intensity, indicating accumulation of lipids. However, particularly to $G$. stomatus, it was observed the liver parenchyma completely filled with fat accumulation (Fig. 4g).

We found parasites in $12.32 \%$ of the individuals of all species, except in G. stomatus. The most affected species were $B$. ronchus and $C$. latus, with 29.16 and $17.14 \%$ of livers infected (Fig. 3b). Parasites were identified as metacercariae of digenetic trematodes (Fig. 5b-d) and myxozoan parasite (Fig. 5a).

Metacercaries were found within the exocrine pancreas and hepatic parenchyma. Its presence has a clear separation within the blood congestion (Fig. 5b) and presents a central portion of indefinite shape, with a circular tendency in pink and branches in yellow. These pathogens were surrounded by a capsule of connective tissue (Fig. 5c). Myxozoan paratise (Fig. 5a) were observed in the bile ducts of B. ronchus which presented granulomas with inflammatory response, the parasite's morphology is mainly composed of collagen fibers, blue in color stained with mallory of trichrome. It occupies the entire bile duct and multiplies within it, increasing the size of this inflammatory capsule.

\subsection{Histopathology of gills}

There were 18 types of alterations in the gills, distributed in 3 stages: stage I (10), stage II (7) and stage III (1) (Fig 6). The most abundant changes were: lifting of epithelial cells $(65.06 \%)$ and fusion of the several secondary lamellae (33.56\%) in stage I, lamellar aneurysm (63.01\%), vessel blood congestion (46.57\%) 
and rupture of the lamellar epithelium (56.16\%) in stage II, and necrosis (34.93\%) in stage III. The necrosis alteration is an irreversible damage.

The histopathological index of gill (HIG) (Fig. 6) in the area 1 was significant different than area 2. In area 1, it was significantly higher in Gobionellus stomatus (93.55 \pm 10.36 ) than in Bairdiella ronchus (66.95 \pm 12.21). In area 2, the HIG did not significantly varied among species. In terms of severity, the rank of HIG were: Gobionellus stomatus $>$ Bairdiella ronchus $>$ Centropomus undecimalis > Centropomus parallelus > Caranx latus. Although all species were considered to have moderate to heavy damaged gills, $C$. undecimalis in area 2 and G. stomatus in area 1 were more impacted. Moreover, clearly, the species caught in the area 1 is more contaminated in relation to the area 2 species. Thus, the anthropized environment were more decisive in relation to the severity of the lesions than the species trophic level.

The frequency of changes was generally divided into four classes, $6.16 \%$ of fish with normally functioning gills ( $H I G=0-10)$, and $13.1 \%$ slightly to moderately damaged gills ( $H I G=11-20)$. The more representative third class (21-50), with $45.89 \%$ of the analyzed species, corresponds to moderately to heavily damaged gills, with more severe changes that can affect normal functioning. In the latter class (33.56\%) (HIG values > 100), it is observed irreparably damaged gills.

In the MDS plot based on gills (Fig. 7a), it was observed spatial differentiation of G. stomatus and $B$. ronchus compared to other species ( $p$ seudo- $F=2.23 ; p<0.05$ ), showing significant different between areas (pseudo- $F=8.06 ; p<0.001$ ). There is a predominance of specific alterations in some species, i.e., $G$. stomatus and $B$. ronchus with necrosis, $C$. parallelus presenting hemorrhage with rupture of epithelium, and $C$. undecimalis with a complete fusion of all the secondary lamellae (Fig. 8c). In general, changes such as necrosis, aneurysm lamellar, rupture of the lamellar epithelium and hemorrhages with rupture of epithelium were present in all studied fish in significant proportions (Fig. 7b and 8).

\section{Discussion}

The use of histopathological biomarkers is widely used to assess the health status of fish in anthropized environments, since it allows the detection of sublethal effects, being a low-cost and easy-to-apply tool. In accordance with our findings obtained with the use of liver and gills and biomarkers, the species evaluated were effective for the diagnosis of environmental impact in the study areas, based on the degree of cellular damage in individuals.

Fish species with different trophic guilds were chosen in this study, which implies that they have different contamination routes (Viana et al. 2013), and then a close correlation with the contamination because of biomagnification process. The trophic guild piscivores (C. undecimalis and B. ronchus) and detritivores (G. stomatus) were more affected, and hence may act as better bioindicators of impacted areas.

Piscivorous species tend to have the greatest contamination effect due to the natural synergistic process of biomagnification. However, detritivorous species such as Gobionellus stomatus from polluted environments can be considered more sensitive to environmental variations, being considered a good indicator of the environmental quality of the estuary, similar to that obtained by (Do Prado et al. 2020). 
It was observed high values of hepatosomatic index ( $\mathrm{HSI})$ in all species. The liver is an organ commonly used to assess contaminant effects and anthropic impact in fish, mainly through morphometric indices such as HSI and condition factor (K). Several studies have already evaluated the positive correlation between liver enlargement and the exposure to chemical pollutants, which can be a metabolic activity during the process of detoxifying contaminants (Schmitt and Dethloff, 2000; Van der Oost et al. 2003). The size of the liver can be used as a tool to monitor the health of fish in impacted aquatic environments (Van der Oost et al. 2003). Higher HSI values are associated to the presence of toxic compounds and, the increase of liver size is a result of hypertrophy and hyperplasia processes, as well as the increasing ability to metabolize xenobiotics (Araújo et al. 2018; da Mata Pavione et al. 2019). This relationship between the high HSI and accumulation of lipids was also reported by Fåhraeus-Van Ree and Spurrell (2003) for Limanda ferruginea from Witless Bay, Newfoundland and Labrador.

As for the $\mathrm{HSI}$, it was observed in $\mathrm{G}$. stomatus the lowest $\mathrm{K}$ value among the analyzed species. The $\mathrm{K}$ is often associated to water quality and food availability, hence indicator of the fish health (Van der Oost et al. 2003; Rossi et al. 2020). This index may be reduced by the presence of pollutants given the increased metabolic activity and demand of energy for detoxification process, altering the fish feeding rate (Heath 1995). All species in the studied estuaries had high values of histopathological alteration index of the liver (HIL) (HIL=45.44 - 67.8). Several authors have proven the efficiency of histopathological biomarkers for environmental monitoring through the HIL, in order to evaluate the health condition of fish (Viana et al. 2013; Kostić et al. 2017; Borges et al. 2018). The observed values were higher than the values recorded for species in other estuarine and coastal areas submitted to anthropic impacts: Solea senegalensis (HIL $<10)$ in contaminated sediments from south of the Gulf of Gabes, Tunisia (Ghribi et al. 2019); Solea senegalensis (HIL<12) in sediment from Sado estuary (Costa et al. 2009); and Solea spp. $(H I L<12)$ in Bilbao estuary (Bay of Biscay) (Briaudeau et al. 2019). In Brazilian estuaries, our indices were much higher those reported for Atherinella brasiliensis $(\mathrm{HIL}<30)$ in the Estuarine-Lagoon Complex of Iguape-Cananéia, São Paulo (Salgado et al. 2018) and Cathorops spixii (HIL<12) in Paranaguá Bay, Brazil (dos Santos et al. 2014).

According Zimmerli et al. (2007), severe histological changes in the tissue (HIL>40) may be categorized as irreparable, like necrosis, that can lead to mortality due to the loss of vital tissue function or increase of susceptibility to disease. The HLI and the HSI are directly related, and possibly correlated - high HSI values lead to high HIL, and vice-versa. High HSI is commonly associated to sublethal impacts of effluents, such as retention zones for contaminants, exposure time and bioavailability of contaminants (da Mata Pavione et al. 2019).

The liver changes found for the studied species ranged from mild to severe, with loss of tissue function, and liver tissue and bile duct necrosis were the most serious injury (72.60\%). Santos et al. (2014) observed necrosis alteration in $100 \%$ of liver of Cathorops spixii when evaluating the effects of bioaccumulation of butyltins in Paranaguá Bay. Khoshnood (2017) reported that different sources of pollution can result in moderate to severe damage to liver cells. Our findings were similar to the obtained by Oliva et al. (2013) with Solea senegalensis in Huelva, Spain; Cathorops spixii in Paranaguá Bay (dos 
Santos et al. 2014), and Arius thalassinus in Hodeida, Yemen Republic (Saleh and Marie 2016). In general, all the studies presented above reported alterations as observed in our study, the liver had an increased vacuolar degeneration, necrotic foci, hemorrhage, leukocyte infiltration, granulomas and parasites when submitted to an anthropofied environment. Among these alterations, the granuloma has a complexity due to the origin of its formation.

Granulomas observed for all species in this study were associated with inflammatory processes, which are capsules surrounded by multiple fibrotic layers involving an inflammatory response (Fricke et al. 2012). This alteration may be a response to environmental stress, or a process initiated by parasites (Araújo et al. 2019), as observed in our study. Parasites affect structure of tissue, increase granulomas, and can cause irreversible damage (Melo et al. 2014). These reaction patterns were similarly observed in all fish species of our study, associated with the presence of parasites. Highly anthropized environments directly affect the immunity of fish that inhabiting this ecosystem, making them more susceptible to parasite infestations(de Melo Souza et al. 2019; Falkenberg et al. 2019; Byers 2020).

All fish specimens evaluated in both areas presented around $95.89 \%$ vacuolization in the liver. It usually occurs due to the storage of lipids or glycogen as an energy source when found in low proportion or minimums, but it is possible to increase if subjected to some stressors like contaminant exposure and nutritional status of the species (Wolf et al. 2015). Oliva et al. (2013) found $100 \%$ vacuolization in the Solea senegalensis, from a polluted estuary in Huelva, Spain.

Gobionellus stomatus had a steatosis in high degree of intensity when compared to other species. The steatosis or fatty degeneration found in all species in this study may be derived from the toxic exposure to pollutants, such as organic compound and heavy metals (Wolf and Wolfe 2005). The severity of this pathology is due to the direct impact on liver functions, enabling an increase in the individual's susceptibility to poison by contaminants (Roberts and Rodger 2012). This pathology in G. stomatus may be associated with a specific response of this species to contaminants, similar results were observed the degenerative processes associated with excessive fat storage in fish from heavily polluted river in Zoarces viviparus of the Baltic Sea (Fricke et al. 2012).

In general, the studied fishes had moderately to heavily damaged degree of gill damage. Some individuals had permanent lesions, such as necrosis, resulting in irreparable damage, indicating that these fish are being subjected to long exposure to toxic agents. The presence of these lesions indicates that a complex mixture of contaminants is present in natural environments affecting the fishes and then health condition (da Silva Montes et al. 2020). Mucous and chloride cells are the cells mostly affected by toxic substances, as they act in the defense and transport mechanism of chloride ions, respectively. These stress-inducing factors can induce pathological changes(David and Fontanetti 2009; Nimet et al. 2020).

In this study, the histopathological index of gills (HIG) ranged from 36.68 to 93.55 . Fishes as histopathological bioindicators to assess environmental contamination are being used by several authors. Carvalho et al. (2020) evaluated Micropogonias furnieri and Menticirrhus americanus (HIG = 
100) from the Bay of Sepetiba-Rio de Janeiro, an area known for the disposal of materials and contaminants, and recorded indexes higher than those reported in the present study. Centropomus undecimalis, with an average HIG of 66.45 , is frequently used as a bioindicator of water quality in impacted areas. Several authors in Maranhão (Brazil) (Cantanhêde et al. 2014, 2016, 2018; Santos et al. 2014) found values lower than the observed in our study (HIG $=19.11$ to 53$)$.

In both estuaries, all fish species had several alterations. In area 1, mainly G. stomatus was more impacted, presented severe lesions, such as necrosis. In general, the histological changes observed in the liver and gills are not of specific origin, being associated with their response when exposed to toxic agents, which can vary from heavy metals, and vinasse to pesticides (Chavan and Muley 2014; Coelho et al. 2018). Even though the studied areas are impacted by different anthropic sources and different severities, such as the launch of 22 to $35 \mathrm{ton} \mathrm{Hg}$ in the area 1 for 24 years and the sugar industry established in area 2 since of the 19th century (Meyer 1996; Pelage et al. 2019), it is difficult to determine the main source that causes histopathological changes in the liver and gills. Heavy metals are responsible for several deleterious effects in fish tissues leading to changes in metabolism, such as hypertrophy ( $\mathrm{Cr}$ ), hyperplasia, lamellar fusion, rupture of epithelium lamellar (Zn), hypertrophy and hyperplasia of primary and secondary lamellae; and liver hepatocytes vacuolations (Cd) (Labarrère et al. 2012; Naiija et al. 2016; Aslam and Yousafzai 2017). Moreover, the release of vinasse in the estuary can favor the appearance of lesions, such as rupture and hemorrhage in the gills(Correia et al. 2017). The pollution of these areas has already been studied by Lopes (2018) which evaluated the pollution in sediments and biota, finding $\mathrm{Hg}$ values above the level 2 established by official agency for the (CONAMA 2012), which means a high probability of toxic effect to biota. This presence of this metal resulted in alteration in neurological physiology, measured by inhibition of AChE activity in $C$. undecimalis, used the as the bioindicator species.

Alterations were more severe for the fish collected in area 1, and correlated to the trophic guild, specially piscivorous and detritivores, which were mostly affected. Gobionellus stomatus had fatty degeneration with a magnitude of severity, totally different from other species. This species and $C$. undecimalis (or of similar genus) are already considered keystone species in these estuaries (Lira et al. 2018) and considering our findings, can also certainly be considered as efficient bioindicators in tropical estuaries. The combination of methodologies pioneering in the Northeast of Brazil, using different species and trophic guilds, was efficient in diagnosing the health status of the area using fish as a bioindicator. There is no study of how these potential damages, evident by the histological alterations, can impact human health, mainly by trophic biomagnification, since the studied species are of great importance to the local community, through a source of food and income. This study serves as a warning to the population that feeds on fish of impacted estuarine areas, such as the present case, and public policies and constant environmental monitoring are needed to investigate the effects of aquatic pollution and consequently, assure safe food to the population.

\section{Declarations}


Acknowledgments

We are grateful to BIOIMPACT Laboratory of the Federal Rural University of Pernambuco for field assistance, Aquaculture Technology Laboratory and the Fisheries Oceanography Laboratory for providing the laboratory structure needed for the analysis (UFRPE). We are also grateful to the Cellular Ultrastructure Laboratories - Institute of Biological Sciences of the Federal University of Pará (UFPA), for the help with histological analyses. This research was funded by PRPPG/UFRPE 015/2018 and is a contribution to LMI TAPIOCA. The Coordination for the Improvement of Higher Education Personnel (CAPES) financed a student grant to the first author, and the National Council for Scientific and Technological Development (CNPq) financed a productivity research grant Flávia Lucena-Frédou and Rossineide Martins da Rocha (308554/2019-1, 307688/2019-4, respectively).

\section{Declaration of Ethics approval and consent to participate}

Not applicable, because of the fish sampled material arrived dead on board, the Brazilian animal ethics committee wasn't required given that any method of sacrifice inside the authorized fishery activity wasn't demanded, therefore their approval wasn't needed

\section{Declaration of Consent for publication}

“Not applicable”

\section{Declaration of Availability of data and materials}

The datasets used and/or analysed during the current study are available from the corresponding author on reasonable request.

\section{Declaration of Competing interests}

The authors declare that they have no competing interests

\section{Declaration of Funding}

This research was funded by PRPPG/UFRPE 015/2018 and is a contribution to LMI TAPIOCA. The Coordination for the Improvement of Higher Education Personnel (CAPES) financed a student grant to the first author, and the National Council for Scientific and Technological Development (CNPq) financed a productivity research grant Flávia Lucena-Frédou and Rossineide Martins da Rocha (308554/2019-1, 307688/2019-4, respectively).

\section{Declaration of Author's contributions}

Ítala Gabriela Sobral dos Santos : Research concept, database process and Roles/Writing - original draft Alex Souza Lira : data analysis and illustrations 
Caroline da Silva Montes : review \& editing

Flávia Lucena-Frédou : Research concept, review \& editing

Rossineide Martins da Rocha : review \& editing

\section{References}

Ali H, Khan E, llahi I (2019) Environmental chemistry and ecotoxicology of hazardous heavy metals: Environmental persistence, toxicity, and bioaccumulation. J Chem 2019:.

https://doi.org/10.1155/2019/6730305

Ameur W Ben, El Megdiche Y, de Lapuente J, et al (2015) Oxidative stress, genotoxicity and histopathology biomarker responses in Mugil cephalus and Dicentrarchus labrax gill exposed to persistent pollutants. A field study in the Bizerte Lagoon: Tunisia. Chemosphere 135:67-74. https://doi.org/10.1016/j.chemosphere.2015.02.050

Anderson MJ (2001) A new method for non -parametric multivariate analysis of variance. Austral Ecology 26: 32-46.

Araújo FG, Gomes ID, Nascimento AA do, et al (2019) Histopathological analysis of liver of the catfish Pimelodus maculatus in a tropical eutrophic reservoir from Southeastern Brazil. Acta Sci - Biol Sci 41:111. https://doi.org/10.4025/actascibiolsci.v41i1.41039

Araújo FG, Morado CN, Parente TTE, et al (2018) Biomarkers and bioindicators of the environmental condition using a fish species (Pimelodus maculatus Lacepède, 1803) in a tropical reservoir in Southeastern Brazil. Brazilian J Biol 78:351-359. https://doi.org/10.1590/1519-6984.167209

Aslam S, Yousafzai AM (2017) Chromium toxicity in fish: A review article. J Entomol Zool Stud 5:14831488

Becker DJ, Chumchal MM, Broders HG, et al (2018) Mercury bioaccumulation in bats reflects dietary connectivity to aquatic food webs. Environ Pollut 233:1076-1085.

https://doi.org/10.1016/j.envpol.2017.10.010

Bernet D, Schmidt H, Meier W, et al (1999) Gonadal alterations in male whitefish Coregonus fatioi: No evidence for genetic damage reducing viability in early life stages. Dis Aquat Organ 61:25-34

Boran M, Altinok I (2010) A review of heavy metals in water, sediment and living organisms in the black sea. Turkish J Fish Aquat Sci 10:565-572. https://doi.org/10.4194/trjfas.2010.0418

Borges AC, Da Silva Montes C, Barbosa LA, et al (2018) Integrated use of histological and ultrastructural biomarkers for assessing mercury pollution in piranhas (Serrasalmus rhombeus) from the Amazon mining region. Chemosphere 202:788-796. https://doi.org/10.1016/j.chemosphere.2018.02.169 
Bray JR, Curtis JT, Roger J (1957) An Ordination Of The Upland Forest Communities Of Southern Wisconsin. Ecol Monogr 27:325-349

Briaudeau T, Zorita I, Cuevas N, et al (2019) Multi-annual survey of health status disturbance in the Bilbao estuary (Bay of Biscay) based on sediment chemistry and juvenile sole (Solea spp.) histopathology. Mar Pollut Bull 145:126-137. https://doi.org/10.1016/j.marpolbul.2019.05.034

Byers JE (2020) Effects of climate change on parasites and disease in estuarine and nearshore environments. PLoS Biol 18:1-12. https://doi.org/10.1371/journal.pbio.3000743

Cantanhêde SM, Campos VCS, Pereira DP, et al (2018) Parasitism in gills of Centropomus undecimalis (Pisces, centropomidae) from a protected area in São Luís, Maranhão, Brazil. Lat Am J Aquat Res 46:377-382. https://doi.org/10.3856/vol46-issue2-fulltext-13

Cantanhêde SM, da Silva Castro G, Pereira NJ, et al (2016) Evaluation of environmental quality of two estuaries in Ilha do Maranhão, Brazil, using histological and genotoxic biomarkers in Centropomus undecimalis (Pisces, Centropomidae). Environ Sci Pollut Res 23:21058-21069.

https://doi.org/10.1007/s11356-016-7294-9

Cantanhêde SM, Medeiros AM, Ferreira JRC, et al (2014) Using histopathological biomarker in gills of Centropomus undecimalis (Bloch, 1972) in assessing the water quality at Ecological Park Laguna da Jansen, São Luís -MA. Arq Bras Med Veterinária e Zootec 66:593-601

Carr MK, Jardine TD, Doig LE, et al (2017) Stable sulfur isotopes identify habitat-specific foraging and mercury exposure in a highly mobile fish community. Sci Total Environ 586:338-346.

https://doi.org/10.1016/j.scitotenv.2017.02.013

Carvalho TLA de B, Nascimento AA Do, Gonçalves CFDS, et al (2020) Assessing the histological changes in fish gills as environmental bioindicators in paraty and sepetiba bays in Rio de Janeiro, Brazil. Lat Am J Aquat Res 48:590-601. https://doi.org/10.3856/vol48-issue4-fulltext-2351

Chavan VR, Muley D V (2014) Effect of heavy metals on liver and gill of fish Cirrhinus mrigala. Int J Curr Microbiol Appl Sci 3:277-288

Chellaiah ER (2018) Cadmium (heavy metals) bioremediation by Pseudomonas aeruginosa: a minireview. Appl Water Sci 8.. https://doi.org/10.1007/s13201-018-0796-5

Cipurkovic A, Trumic l, Hodžic Z, et al (2014) Distribution of heavy metals in Portland cement production process. Adv Appl Sci Res 5:252-259

Coelho MPM, Correia JE, Vasques LI, et al (2018) Toxicity evaluation of leached of sugarcane vinasse: Histopathology and immunostaining of cellular stress protein. Ecotoxicol Environ Saf 165:367-375. https://doi.org/10.1016/j.ecoenv.2018.08.099 
CONAMA (2012) Conselho Nacional do Meio Ambiente

Core Team R (2020). R: A language and environment for statistical computing. Vienna, Austria: R Founda- tion for Statistical Computing. Available: https://www.rproject.org.

Correia JE, Christofoletti CA, Marcato ACC, et al (2017) Histopathological analysis of tilapia gills (Oreochromis niloticus Linnaeus, 1758) exposed to sugarcane vinasse. Ecotoxicol Environ Saf 135:319326. https://doi.org/10.1016/j.ecoenv.2016.10.004

Costa PM, Diniz MS, Caeiro S, et al (2009) Histological biomarkers in liver and gills of juvenile Solea senegalensis exposed to contaminated estuarine sediments: A weighted indices approach. Aquat Toxicol 92:202-212. https://doi.org/10.1016/j.aquatox.2008.12.009

CPRH (2011) Área de Proteção Ambiental de Guadalupe. 87

da Mata Pavione P, da Costa KG, Perônico C, et al (2019) Development of environmental effects monitoring protocol in Brazil: a fish guide study of three river estuaries. Environ Monit Assess 191:. https://doi.org/10.1007/s10661-019-7860-y

da Silva Montes C, Pantoja Ferreira MA, Giarrizzo T, et al (2020) Evaluation of metal contamination effects in piranhas through biomonitoring and multi biomarkers approach. Heliyon 6:e04666. https://doi.org/10.1016/j.heliyon.2020.e04666

Dalzochio T, Rodrigues GZP, Petry IE, et al (2016) The use of biomarkers to assess the health of aquatic ecosystems in Brazil: a review. Int Aquat Res 8:283-298. https://doi.org/10.1007/s40071-016-0147-9

David JAO, Fontanetti CS (2009) The Role of Mucus in Mytella falcata (Orbigny 1842) Gills from Polluted Environments. Water Air Soil Pollut 203:261-266. https://doi.org/10.1007/s11270-009-0009-9

de Melo Souza DC, dos Santos MC, Chagas EC (2019) Immune response of teleost fish to helminth parasite infection. Rev Bras Parasitol Vet 28:533-547. https://doi.org/10.1590/s1984-29612019080

Dellamatrice PM, Monteiro RTR (2014) Main aspects of the pollution in Brazilian rivers by pesticides. Rev Bras Eng Agric e Ambient 18:1296-1301. https://doi.org/10.1590/1807-1929/agriambi.v18n12p12961301

Do Prado MR, De Carvalho DR, Alves CBM, et al (2020) Convergent responses of fish belonging to different feeding guilds to sewage pollution. Neotrop Ichthyol 18:1-20. https://doi.org/10.1590/19820224-2019-0045

dos Santos DM, Santos GS, Cestari MM, et al (2014) Bioaccumulation of butyltins and liver damage in the demersal fish Cathorops spixii (Siluriformes, Ariidae). Environ Sci Pollut Res 21:3166-3174. https://doi.org/10.1007/s11356-013-2280-y 
Elliott M, Whitfield AK, Potter IC, et al (2007) The guild approach to categorizing estuarine fish assemblages: A global review. Fish Fish 8:241-268. https://doi.org/10.1111/j.1467-2679.2007.00253.x

Fåhraeus-Van Ree GE, Spurrell DR (2003) Structure of and energy reserves in the liver of wild and cultured yellowtail flounder, Limanda ferruginea. Mar Biol 143:257-265. https://doi.org/10.1007/s00227-0031083-y

Falkenberg JM, Golzio JESA, Pessanha A, et al (2019) Gill parasites of fish and their relation to host and environmental factors in two estuaries in northeastern Brazil. Aquat Ecol 53:109-118. https://doi.org/10.1007/s10452-019-09676-6

Fonseca AR, Sanches Fernandes LF, Fontainhas-Fernandes A, et al (2016) From catchment to fish: Impact of anthropogenic pressures on gill histopathology. Sci Total Environ 550:972-986. https://doi.org/10.1016/j.scitotenv.2016.01.199

Fricke NF, Stentiford GD, Feist SW, Lang T (2012) Liver histopathology in Baltic eelpout (Zoarces viviparus) - A baseline study for use in marine environmental monitoring. Mar Environ Res 82:1-14. https://doi.org/10.1016/j.marenvres.2012.08.012

Ghribi R, Correia AT, Elleuch B, Nunes B (2019) Testing the impact of contaminated sediments from the southeast marine coast of Tunisia on biota: a multibiomarker approach using the flatfish Solea senegalensis. Environ Sci Pollut Res 26:29704-29721. https://doi.org/10.1007/s11356-019-05872-x

Heath AG (1995) Water Pollution And Fish Physiology

Hook SE, Gallagher EP, Batley GE (2014) The role of biomarkers in the assessment of aquatic ecosystem health. Integr Environ Assess Manag 10:327-341. https://doi.org/10.1002/ieam.1530

Kameli MA, Chorom M, Jaafarzadeh N, Janadeleh H (2017) Application of wastewater with high organic load for saline-sodic soil reclamation focusing on soil purification ability. Glob J Environ Sci Manag 3:197-206. https://doi.org/10.22034/gjesm.2017.03.02.008

Khoshnood Z (2017) Effects of Environmental Pollution on Fish: A Short Review. Transylvanian Rev Syst Ecol Res 19:49-60. https://doi.org/10.1515/trser-2017-0005

Kostić J, Kolarević S, Kračun-Kolarević M, et al (2017) The impact of multiple stressors on the biomarkers response in gills and liver of freshwater breams during different seasons. Sci Total Environ 601602:1670-1681. https://doi.org/10.1016/j.scitotenv.2017.05.273

Kroon F, Streten C, Harries S (2017) A protocol for identifying suitable biomarkers to assess fish health: A systematic review

Labarrère CR, Menezes BD, Melo MM (2012) Avaliação Dos Teores De Zinco Em Brânquias, Carcaça, Fígado e Musculatura De Diferentes Espécies De Peixes Capturados No Rio São Francisco (Mg, Brasil). 
Geonomos 20:86-91. https://doi.org/10.18285/geonomos.v20i1.31

Lira A, Angelini R, Le Loc'h F, et al (2018) Trophic flow structure of a neotropical estuary in northeastern Brazil and the comparison of ecosystem model indicators of estuaries. J Mar Syst 182:31-45. https://doi.org/10.1016/j.jmarsys.2018.02.007

Lopes DFC (2018) O uso da ictiofauna como bioindicadora de qualidade ambiental de estuários neotropicais. Federal Rural University of Pernambuco

Maia LP, Lacerda LD, Monteiro LHU, Souza GM (eds) (2006) Atlas dos manguezais do nordeste doBrasil

Macêdo, SJ, Flores Montes, MJ, Lins, IC (2000) Características abióticas da área. In Gerenciamento participativo de estuários e manguezais, in Barros, HM, Eskinazi- Leça, E, Macêdo, SJ, Lima, T (Eds), pp. 7-25

Medeiros C, Kjerfve B, Neumann-Leitão S (2001) Coastal Marine Ecosystems of Latin America. In: Seeliger U, Kjerfve B (eds). pp 71-82

Melo FT de V, Rodrigues RAR, Giese EG, et al (2014) Histopathologic aspects in Plagioscion squamosissimus (HECKEL, 1940) induced by Neoechinorhynchus veropesoi, metacestodes and anisakidae juveniles TT - Aspectos histopatólogicos em Plagioscion squamosissimus induzidos por Neoechinorhynchus veropesoi, met. Rev bras parasitol vet 23:224-230

Meyer, U (1996) On the fate of mercury in the northeastern Brazilian mangrove system

Canal de Santa Cruz, Pernambuco. 105f. DD Thesis. Bremen, Germany.

Moura ARLU de, Candeias ALB (2009) A multi-temporal remote sensing and gis based inventory of the mangroves at Itamaracá estuarine system, Northeastern Brazil. Trop Oceanogr 37 :.

https://doi.org/10.5914/tropocean.v37i1-2.5154

Mourão KRM, Ferreira V, Lucena-Frédou F (2014) Composition of functional ecological guilds of the fish fauna of the internal sector of the Amazon estuary, Pará, Brazil. An Acad Bras Cienc 86:1783-1800. https://doi.org/10.1590/0001-3765201420130503

Naidu R, Arias Espana VA, Liu Y, Jit J (2016) Emerging contaminants in the environment: Risk-based analysis for better management. Chemosphere 154:350-357.

https://doi.org/10.1016/j.chemosphere.2016.03.068

Naiija A, Marchand J, Kestemont P, et al (2016) Biomarkers assessment in the peacock blenny Salaria pavo exposed to cadmium. Environ Sci Pollut Res 23:16296-16312. https://doi.org/10.1007/s11356016-6754-6 
Nimet J, Neves MP, Viana NP, et al (2020) Histopathological alterations in gills of a fish (Astyanax bifasciatus) in neotropical streams: negative effects of riparian forest reduction and presence of pesticides. Environ Monit Assess 192:. https://doi.org/10.1007/s10661-019-8030-y

Oksanen J, Blanchet FG, Friendly M, et al (2017) Package "vegan": Community Ecology Package. R package version 2.4-4. Reference manual. 297

Oliva M, Vicente-Martorell JJ, Galindo-Riaño MD, Perales JA (2013) Histopathological alterations in Senegal sole, Solea Senegalensis, from a polluted Huelva estuary (SW, Spain). Fish Physiol Biochem 39:523-545. https://doi.org/10.1007/s10695-012-9717-y

Pacyna JM, Sundseth K, Pacyna EG, et al (2010) An assessment of costs and benefits associated with mercury emission reductions from major anthropogenic sources. J Air Waste Manag Assoc 60:302-315. https://doi.org/10.3155/1047-3289.60.3.302

Pelage L, Domalain G, Lira AS, et al (2019) Coastal Land Use in Northeast Brazil: Mangrove Coverage Evolution Over Three Decades. Trop Conserv Sci 12:. https://doi.org/10.1177/1940082918822411

Poleksic V, Mitrovic-Tutundzic V (1994) Fish gills as a monitor of sublethal and chronic effects of pollution. In: Sublethal and Chronic Effects of Pollutants on Freshwater Fish. Sublethal Chronic Eff Pollut Freshw Fish 339-352

Prophet, EB, Milis, B, Arrington, JB, Sobin, LH (1995). Metodos Histotecnologicos.Instituto de Patologia de las Fuerzas Armadas de los Estados Unidos de America (AFIP), Washington (DC), p. 280

Roberts RJ, Rodger HD (2012) The Pathophysiology and Systematic Pathology of Teleosts. In: Roberts RJ (ed) Fish Pathology. p 587

Rossi AS, Fantón N, Michlig MP, et al (2020) Fish inhabiting rice fields: Bioaccumulation, oxidative stress and neurotoxic effects after pesticides application. Ecol Indic 113:106186.

https://doi.org/10.1016/j.ecolind.2020.106186

Salas PM, Sujatha CH, Ratheesh Kumar CS, Cheriyan E (2017) Heavy metal distribution and contamination status in the sedimentary environment of Cochin estuary. Mar Pollut Bull 119:191-203. https://doi.org/10.1016/j.marpolbul.2017.04.018

Saldarriaga-Hernandez S, Hernandez-Vargas G, Iqbal HMN, et al (2020) Bioremediation potential of Sargassum sp. biomass to tackle pollution in coastal ecosystems: Circular economy approach. Sci Total Environ 715:. https://doi.org/10.1016/j.scitotenv.2020.136978

Saleh YS, Marie MAS (2016) Use of Arius thalassinus fish in a pollution biomonitoring study, applying combined oxidative stress, hematology, biochemical and histopathological biomarkers: A baseline field study. Mar Pollut Bull 106:308-322. https://doi.org/10.1016/j.marpolbul.2016.03.030 
Salgado LD, Marques AEML, Kramer RD, et al (2018) Integrated assessment of sediment contaminant levels and biological responses in sentinel fish species Atherinella brasiliensis from a sub-tropical estuary in south Atlantic. Chemosphere 219:15-27. https://doi.org/10.1016/j.chemosphere.2018.11.204

Santos DMS, Melo MRS, Mendes DCS, et al (2014) Histological changes in gills of two fish species as indicators of water Quality in Jansen Lagoon (São Luís, Maranhão State, Brazil). Int J Environ Res Public Health 11:12927-12937. https://doi.org/10.3390/ijerph111212927

Schmitt CJ, Dethloff GM (2000) Biomonitoring of Environmental Status and Trends (BEST) Program: selected methods for monitoring chemical contaminants and their effects in aquatic ecosystems

Silva JB da, Galvíncio JD, Corrêa ACDB, et al (2011) Classificação Geomorfológica dos Estuários do Estado de Pernambuco (Brasil) com Base em Imagens do LANDSAT 5/TM (Geomorphologic Classification of Estuaries of the State of Pernambuco (Brazil) Based on Landsat 5 TM Images). Rev Bras Geogr Física 4:118. https://doi.org/10.26848/rbgf.v4i1.232689

Slooff W, Van Kreijl CF, Baars AJ (1983) Relative liver weights and xenobiotic-metabolizing enzymes of fish from polluted surface waters in the Netherlands. Aquat Toxicol 4:1-14. https://doi.org/10.1016/0166-445X(83)90057-7

Smolders R, Bervoets L, De Boeck G, Blust R (2002) Integrated Condition Indices As a Measure of Whole Effluent Toxicity in Zebrafish (Danio Rerio). Environ Toxicol Chem 21:87. https://doi.org/10.1897/15515028(2002)021<0087:iciaam>2.0.co;2

Terra BF, Araújo FG, Calza CF, et al (2008) Heavy metal in tissues of three fish species from different trophic levels in a tropical Brazilian river. Water Air Soil Pollut 187:275-284.

https://doi.org/10.1007/s11270-007-9515-9

Todorov V, Filzmoser P (2009) An Object-Oriented Framework for Robust. J Stat Softw 32:1-47

Van der Oost R, Beyer J, Vermeulen NPE (2003) Fish bioaccumulation and biomarkers in environmental risk assessment: a review. Environ Toxicol Pharmacol 13:57-149

Viana AP, Frédou FL, Montes C da S, Rocha RM (2013) Fish histopathology and catalase activity as biomarkers of the environmental quality of the industrial district on the Amazon estuary, Brazil. Acta Sci Biol Sci 35:395-401. https://doi.org/10.4025/actascibiolsci.v35i3.18032

Vieira CED, Costa PG, Caldas SS, et al (2019) An integrated approach in subtropical agro-ecosystems: Active biomonitoring, environmental contaminants, bioaccumulation, and multiple biomarkers in fish. Sci Total Environ 666:508-524. https://doi.org/10.1016/j.scitotenv.2019.02.209

Wang WX (2002) Interactions of trace metals and different marine food chains. Mar Ecol Prog Ser 243:295-309. https://doi.org/10.3354/meps243295 
Willacker JJ, Eagles-Smith CA, Ackerman JT (2017) Mercury Bioaccumulation in Estuarine Fishes: Novel Insights from Sulfur Stable Isotopes. Environ Sci Technol 51:2131-2139.

https://doi.org/10.1021/acs.est.6b05325

Wolf JC, Baumgartner WA, Blazer VS, et al (2015) Nonlesions, Misdiagnoses, Missed Diagnoses, and Other Interpretive Challenges in Fish Histopathology Studies:A Guide for Investigators, Authors, Reviewers, and Readers. Toxicol Pathol 43:297-325. https://doi.org/10.1177/0192623314540229

Wolf JC, Wolfe MJ (2005) A Brief Overview of Nonneoplastic Hepatic Toxicity in Fish. Toxicol Pathol 33:75-85. https://doi.org/10.1080/01926230590890187

Zimmerli S, Bernet D, Burkhardt-Holm P, et al (2007) Assessment of fish health status in four Swiss rivers showing a decline of brown trout catches. Aquat Sci 69:11-25. https://doi.org/10.1007/s00027-0060844-3

\section{Tables}

Table 1 Classification of histopathological changes of gill and liver in relation to the type, location and stage of lesions in which they occur. Modified from Poleksić and Mitrovic - Tutundzic (1994) for gills (stage) and Bernet et al. (1999) for liver (importance factor). 


\begin{tabular}{|c|c|}
\hline GILL/LIVER HISTOPATHOLOGY & STAGE/IMPORTANCE FACTOR \\
\hline \multicolumn{2}{|l|}{ Hypertrophy and hyperplasia of gill epithelium } \\
\hline Hypertrophy of respiratory epithelium & I \\
\hline Lifting of epithelial cells & I \\
\hline Lamellar epithelial hyperplasia & I \\
\hline Focal hyperplasia of epithelial cells & 1 \\
\hline Leukocyte infiltration of gill epithelium & I \\
\hline Derangement lamellar & I \\
\hline Incomplete fusion of some lamellae & I \\
\hline Parasites & I \\
\hline Complete fusion of all lamellae & II \\
\hline Rupture of the lamellar epithelium & II \\
\hline Uncontrolled proliferation of tissue & II \\
\hline Necrosis & III \\
\hline \multicolumn{2}{|l|}{ Changes in mucous cells } \\
\hline Hypertrophy and hyperplasia of mucuos cells & 1 \\
\hline \multicolumn{2}{|l|}{ Changes in blood vessels } \\
\hline Filament blood vessel enlargement & I \\
\hline Vessel blood congestion & ॥ \\
\hline Hemorrhages with rupture of epithelium & II \\
\hline Lamellar telangiectasis & II \\
\hline Aneurysm Lamellar & II \\
\hline \multicolumn{2}{|l|}{ Changes in hepatocytes } \\
\hline Cytoplasm alteration & 1 \\
\hline Hepatic steatosis & 1 \\
\hline Hepatic parenchyma & 1 \\
\hline
\end{tabular}




\begin{tabular}{|l|l|}
\hline Nuclear alterations & II \\
\hline Necrosis & III \\
\hline Cell hypertrophy & III \\
\hline Cell hyperplasia & I \\
\hline Infiltration of leucocytes & II \\
\hline Parasites & II \\
\hline Wall proliferation of bile ducts & III \\
\hline Changes in blood vessels & I \\
\hline Haemorrhage/aneurysm & \\
\hline
\end{tabular}

Table 2 Morphometric data and gross index for the analyzed species in the study area. Data represented as mean \pm standard deviation, $n$ - number of individuals analyzed, HSI- hepatosomatic index, CFcondition factor, Area 1 (Santa Cruz Channel Estuary), Area 2 (Sirinhaém).

\begin{tabular}{lllllll} 
Species & $\mathbf{n}$ & Area & $\begin{array}{l}\text { Standard } \\
\text { Length }(\mathbf{c m})\end{array}$ & Body mass $(\mathbf{g})$ & HSI & CF \\
\hline Bairdiella ronchus & 24 & SCC & $14.17 \pm 1.38$ & $34.74 \pm 11.66$ & $1.13 \pm 0.42$ & $1.97 \pm 0.15$ \\
\hline Gobionellus stomatus & 34 & SCC & $14.36 \pm 3.18$ & $11.96 \pm 5.91$ & $3.82 \pm 3.31$ & $1.01 \pm 0.25$ \\
\hline Centropomus undecimalis & 24 & SIR & $24.5 \pm 3.05$ & $101.9 \pm 37.38$ & $0.91 \pm 0.28$ & $1.23 \pm 0.17$ \\
\hline Centropomus parallelus & 29 & SIR & $17.9 \pm 2.1$ & $55.18 \pm 21.85$ & $0.90 \pm 0.17$ & $1.85 \pm 0.16$ \\
\hline Caranx latus & 35 & SIR & $12.49 \pm 1.1$ & $27.32 \pm 8.8$ & $1.06 \pm 0.35$ & $2.68 \pm 0.22$
\end{tabular}

\section{Figures}




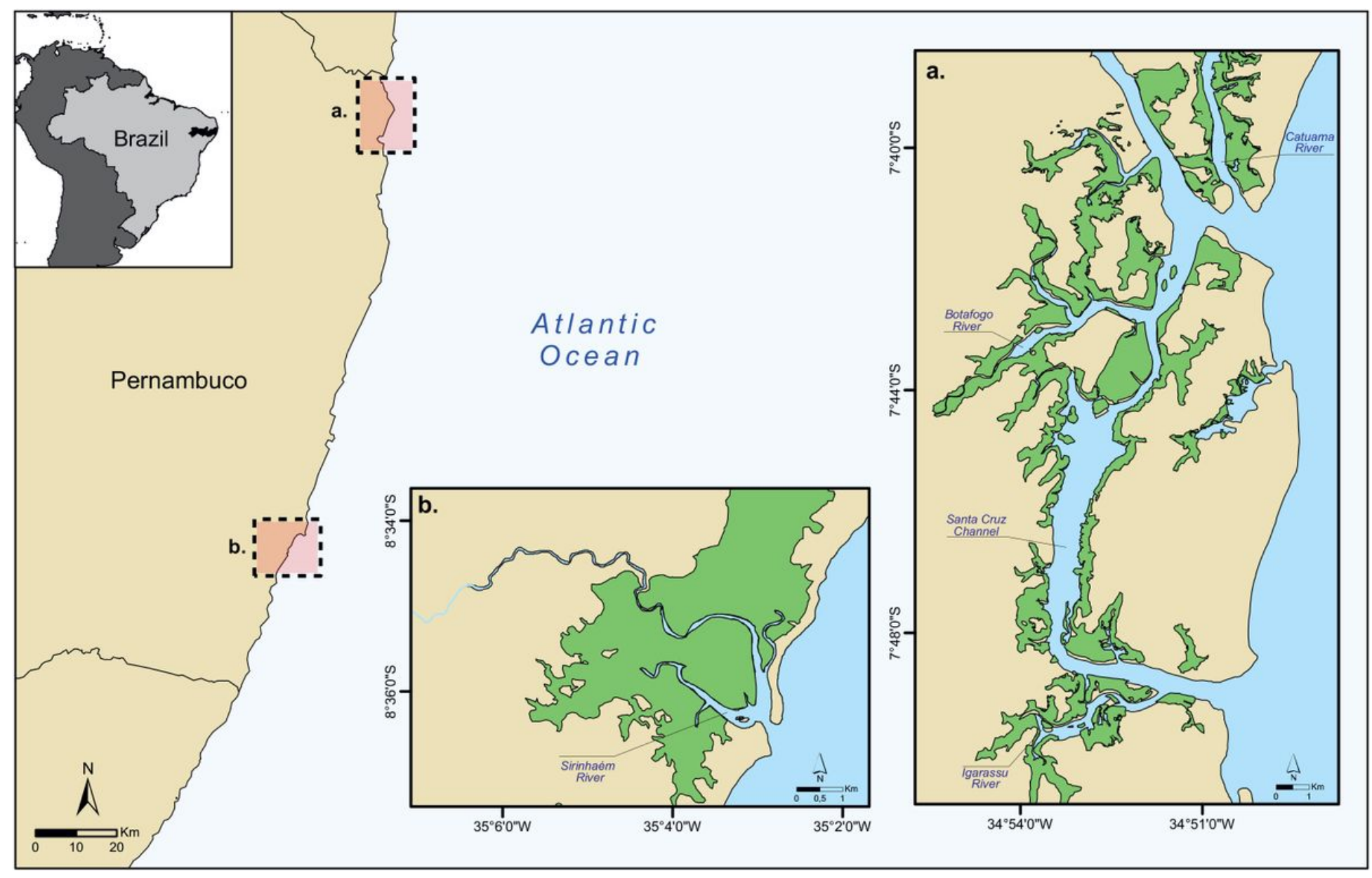

Figure 1

Study area located on the Pernambuco coast in northeast Brazil, a) represents Santa Cruz Channel Estuary (area 1) and b) Sirinhaém (area 2). 


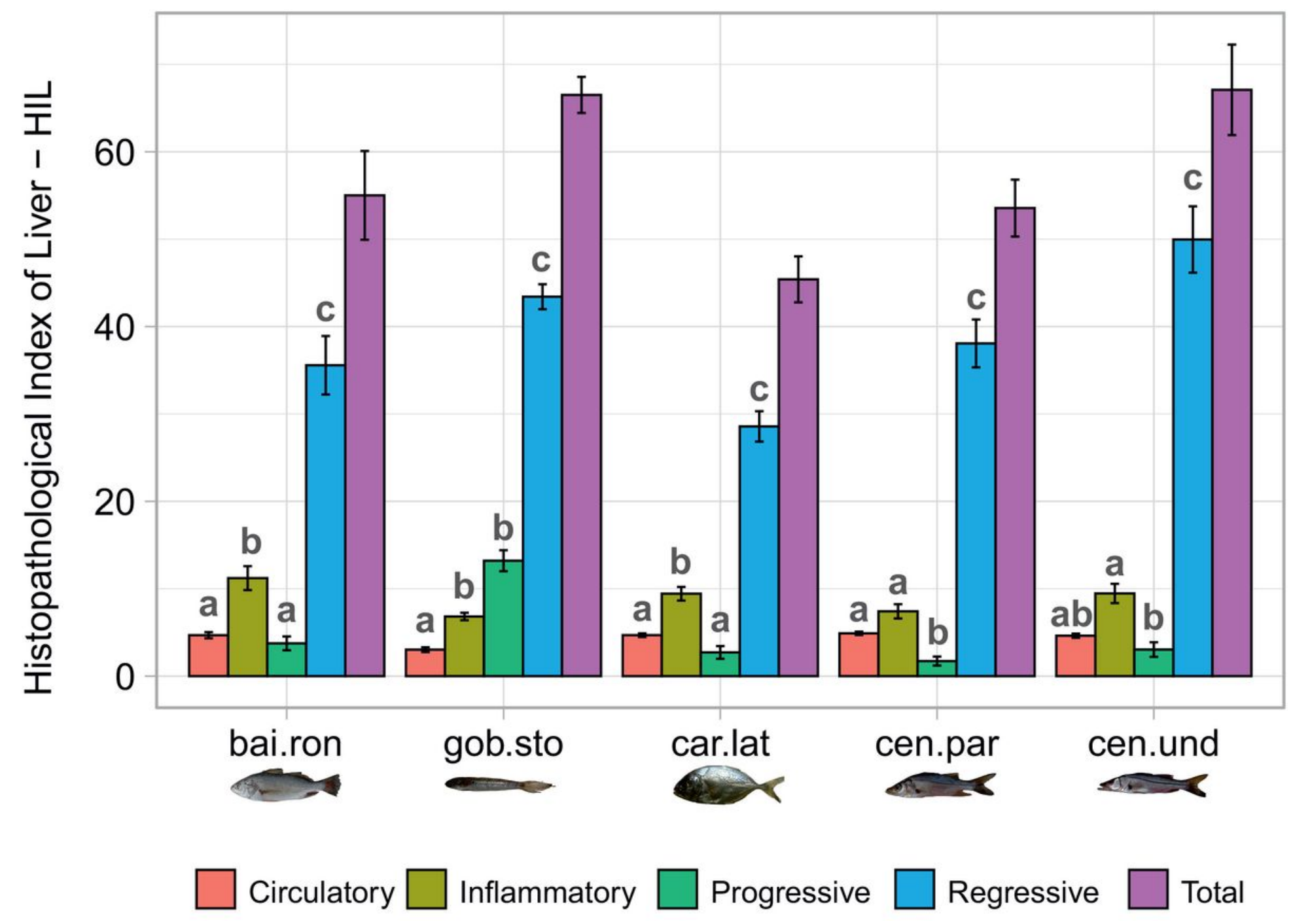

Figure 2

Histopathological index of gills (mean \pm SD) by studied species. Letters indicate the results of Nemenyi tests among species. Bai.ron- Bairdiella ronchus, Gob.sto- Gobionellus stomatus, Car.lat- Caranx latus, Cen.par- Centropomus parallelus, Cen.und- Centropomus undecimalis. 
a)

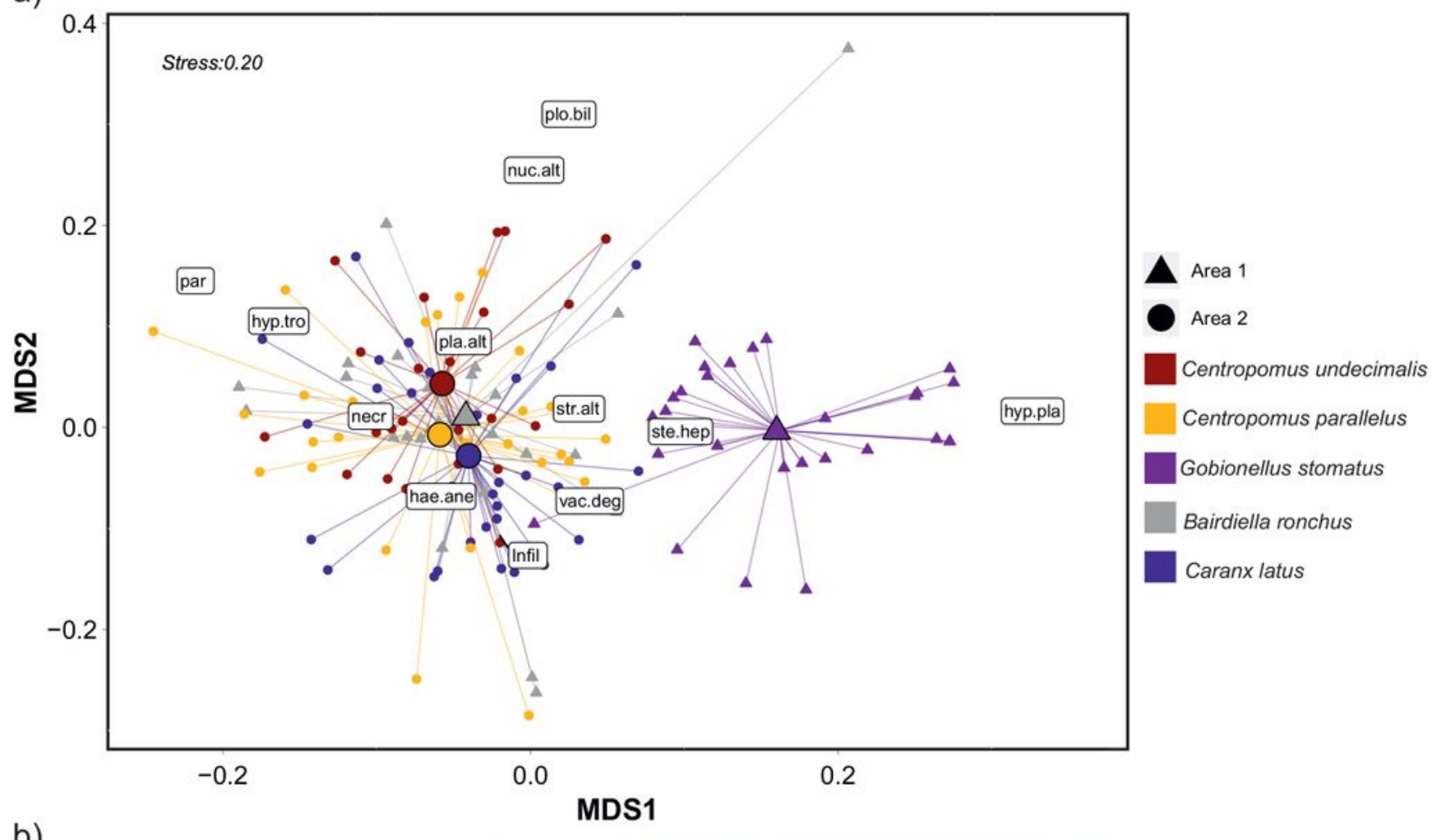

b)

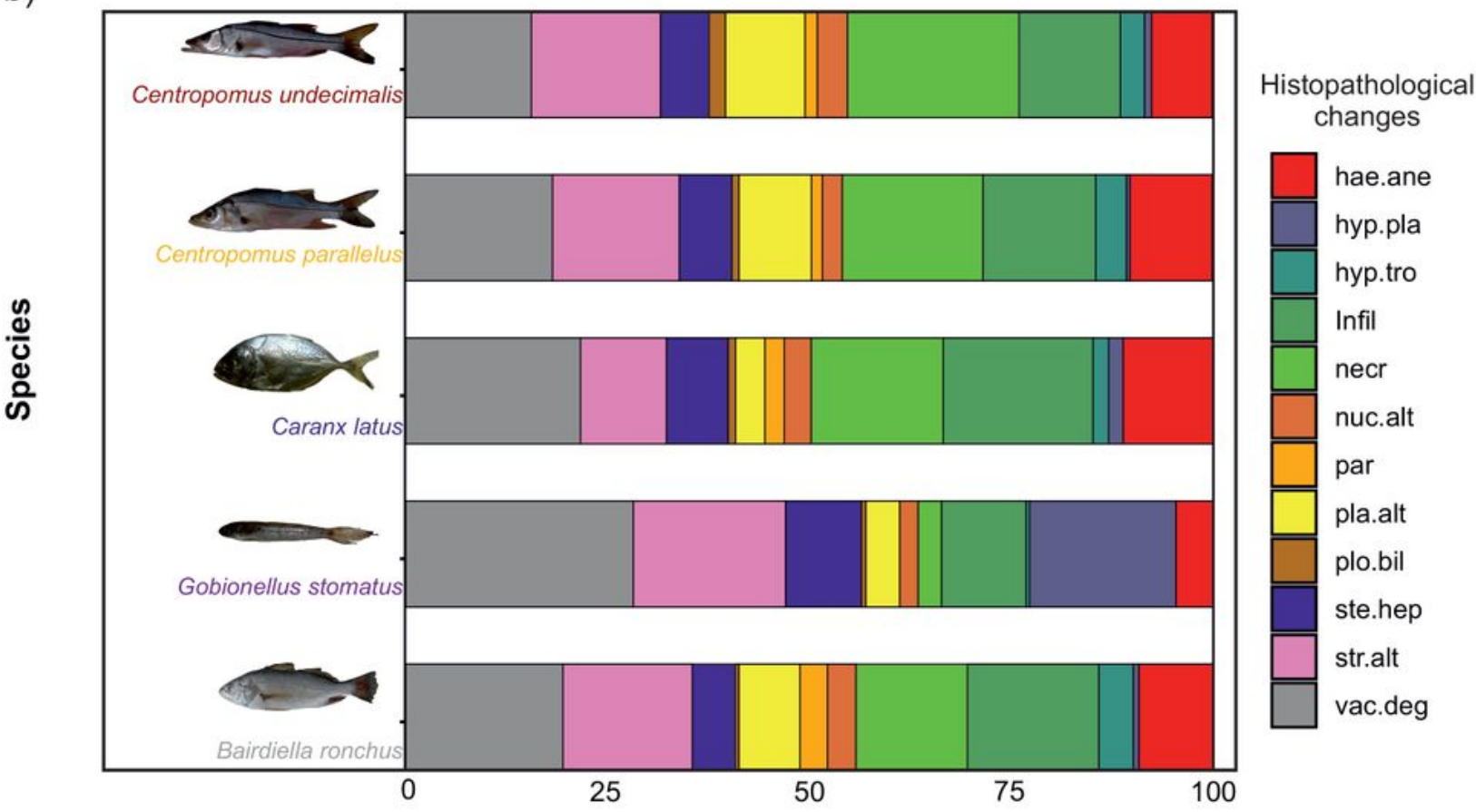

Frequency of occurrence - \%FO

\section{Figure 3}

Analysis of multidimensional scaling (MDS) with histopathological changes of the liver (a) and the frequency of occurrence of changes (b), hae.ane (haemorrhage/hyperaemia), hyp.tro (hypertrophy), hyp.pla (hyperplasia), Infil (infiltration), necr (necrosis), nuc.alt (nuclear alterations), par (parasite), pla.alt (cytoplasm alterations), ste.hep (steatosis hepatic), plo.bil (wall proliferation of bile ducts), str.alt (Architectural and structural alteration), vac.deg (vacuolar degeneration). 

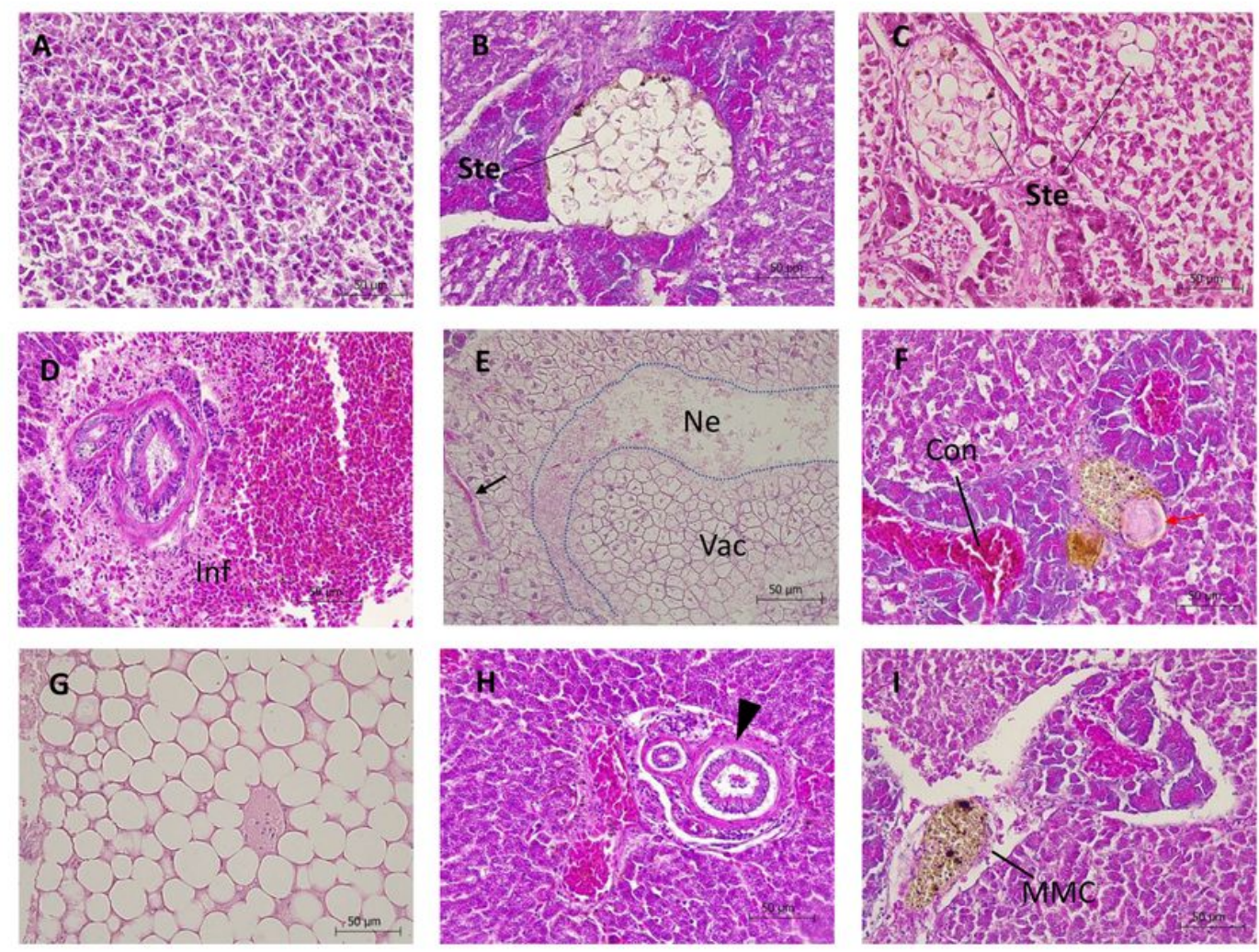

\section{Figure 4}

. Histopathological changes in the liver of the analyzed species, C. parallelus (a,c), B. ronchus (e), C.

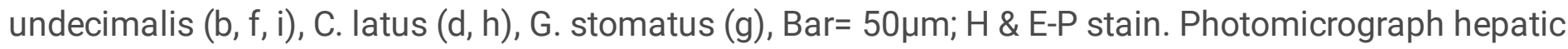
tissue [a] Normal structural architecture ; [b] extensive hepatic steatosis (Ste); [c] hepatic steatosis (Ste) allocated to exocrine tissue and dispersed in the hepatic parenchyma; [d] Inflammation by leukocyte infiltrate (Inf); [e] leukocyte infiltrate (arrow), vacuolated hepatocytes (Vac) and necrosis ( $\mathrm{Ne}$ ); [f] granuloma (red arrow), blood cell congestion within the exocrine pancreas (Con); [g] severe fatty degeneration; [h] hypertrophy of bile duct;; [i] melano-macrophage centers. 

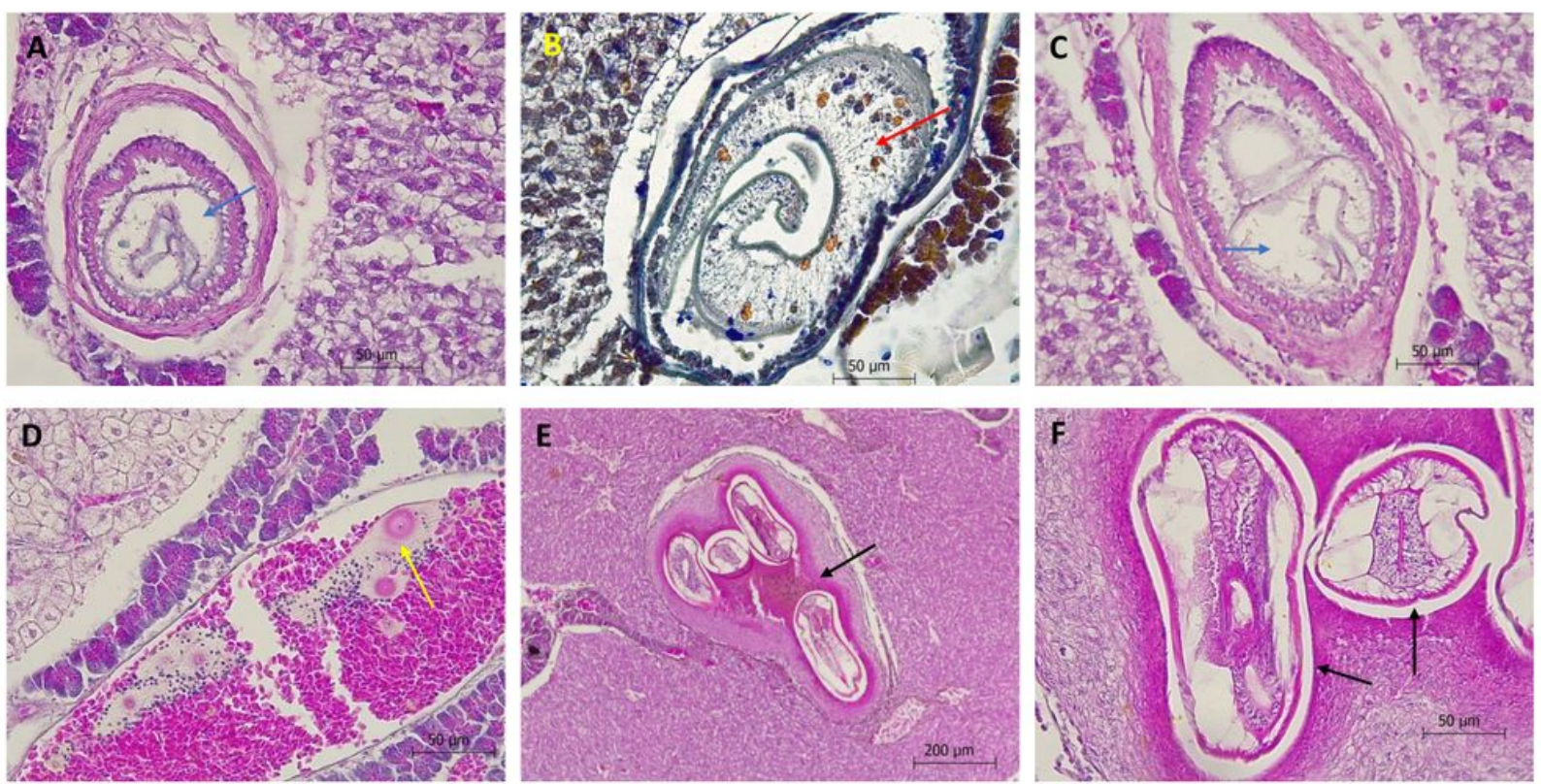

\section{Figure 5}

Histopathological changes in the liver of the analyzed species, B. ronchus (a,b, c), C. undecimalis (d, e, f), Bar $=50 \mu \mathrm{m}(\mathrm{a}, \mathrm{b}, \mathrm{d}) ; 200 \mu \mathrm{m}(\mathrm{c}), \mathrm{H} \& \mathrm{E}-\mathrm{P}$ stain, mallory of trichrome stain (b), [a] Sporoplasms of a myxozoan paratise into the bile ducts (blue arrow); [b] Sporoplasms of a myxozoan paratise into the bile ducts (red arrow); [c] Initial of sporoplasms of a myxozoan paratise into the bile ducts (blue arrow);[d] metacercariae of digenetic trematodes within the blood vessel (yellow arrow); [e] metacercariae of digenetic trematodes inside an envelope capsule (black arrow); [f] metacercariae of digenetic trematodes inside an envelope capsule (black arrow). 


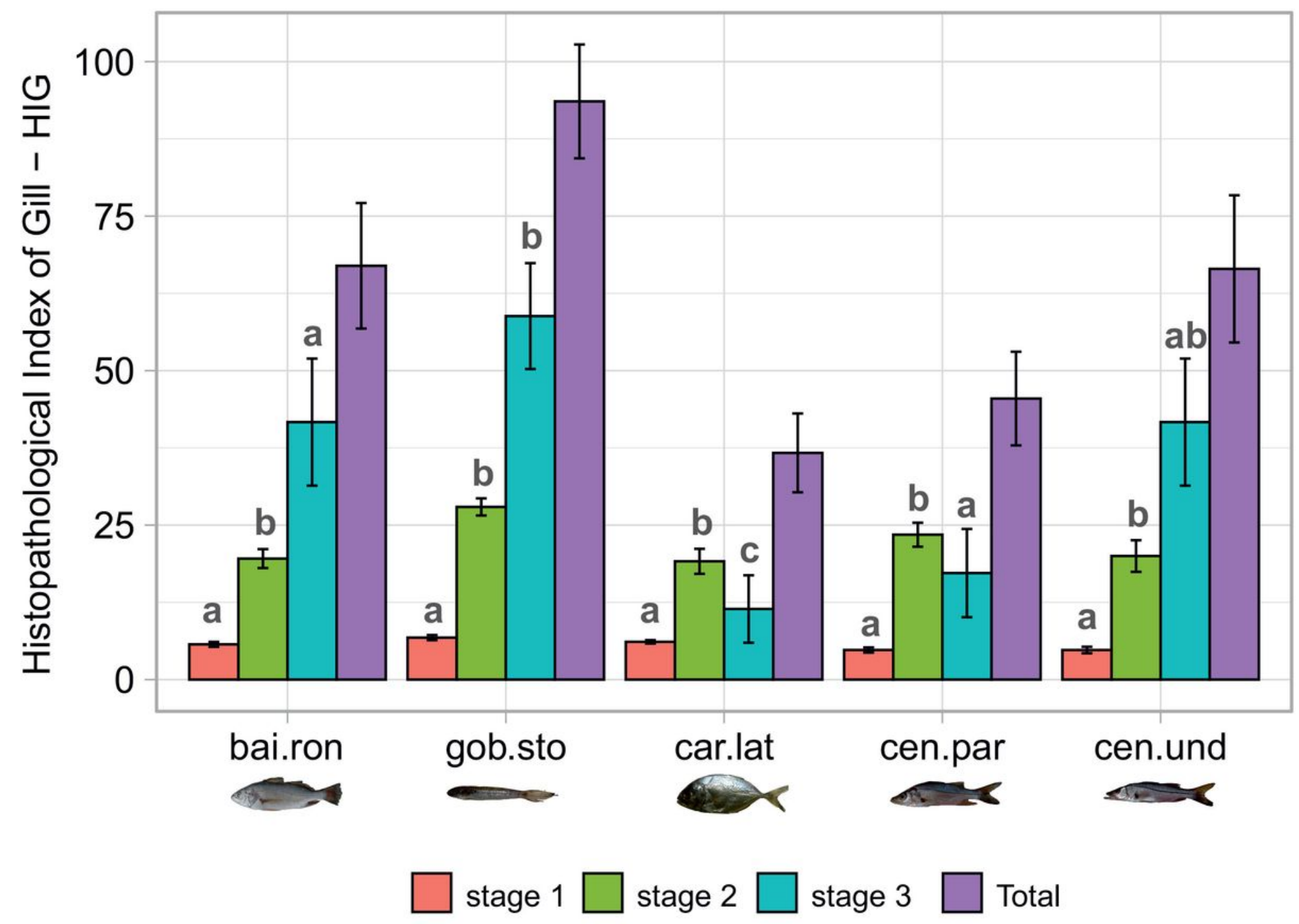

Figure 6

Histopathological index of gills (mean \pm SD) by studied species. Letters indicate the results of Nemenyi tests among species. Bai.ron- Bairdiella ronchus, Gob.sto- Gobionellus stomatus, Car.lat- Caranx latus, Cen.par- Centropomus parallelus, Cen.und- Centropomus undecimalis. 


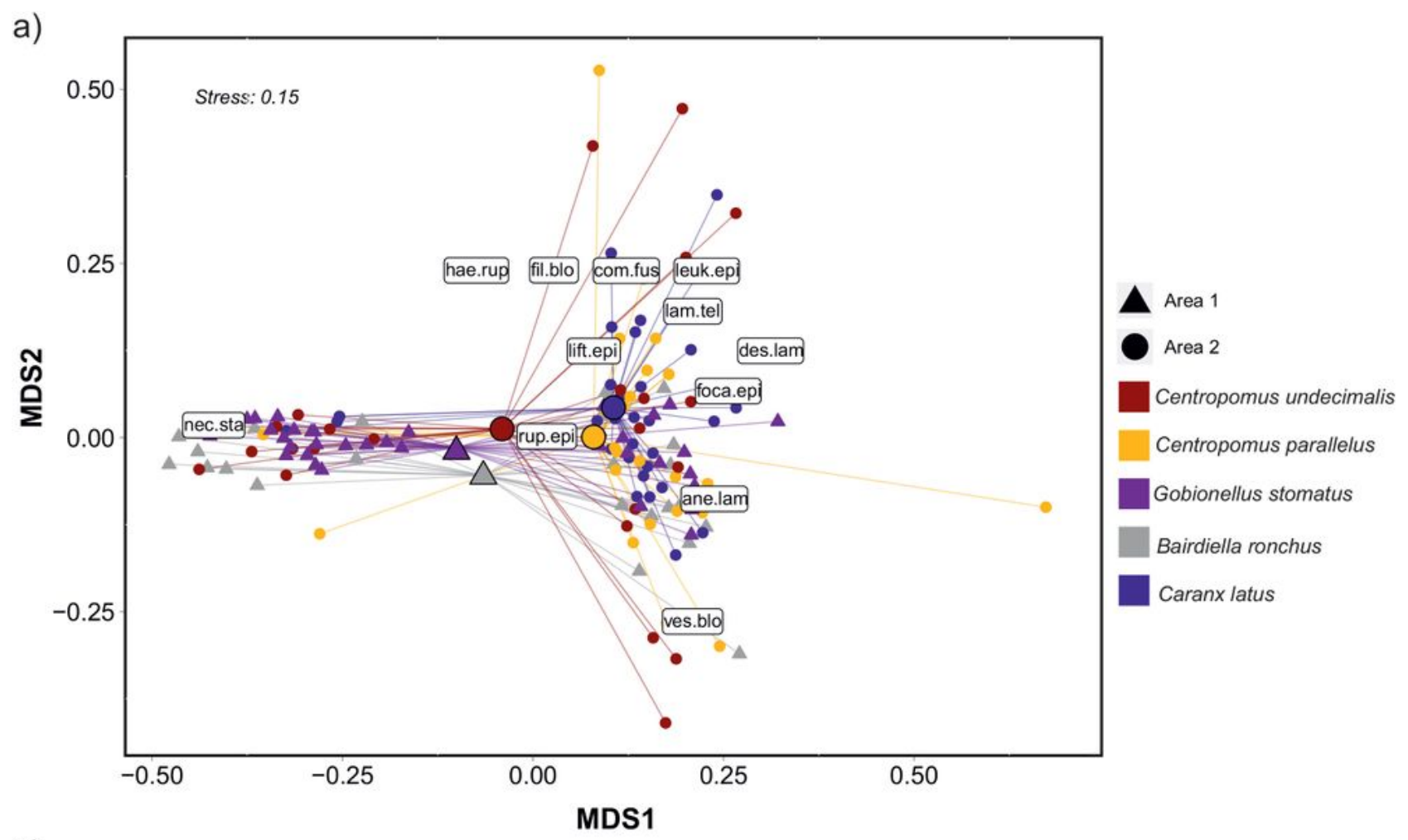

b)

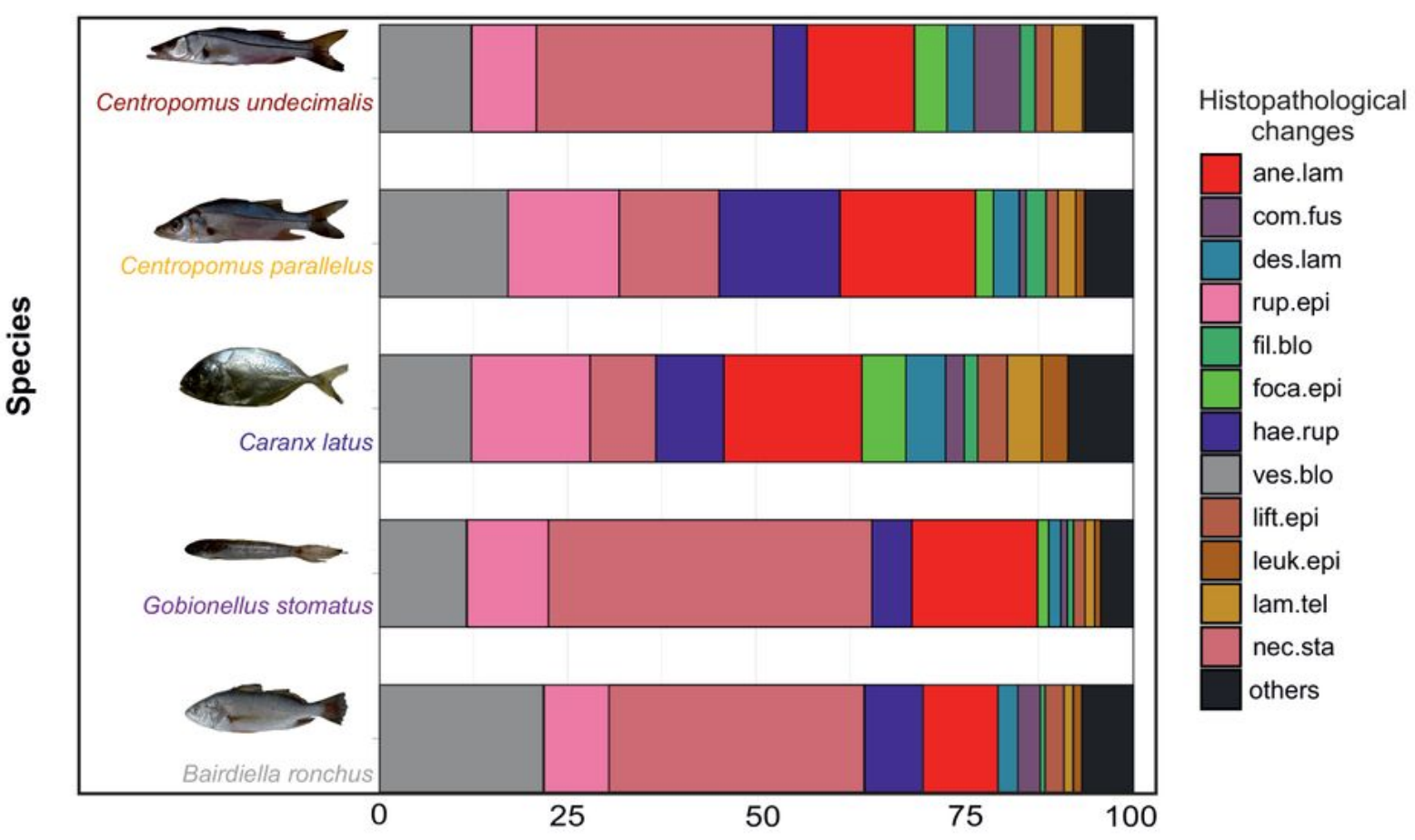

Frequency of occurrence - \%FO

\section{Figure 7}

Analysis of multidimensional scaling (MDS) with histopathological changes of the gills (a) and the frequency of occurrence of changes (b), ane.lam (aneurysm lamellar), com.fus (complete fusion of all the secondary lamellae), des.lam (derangement lamellar), rup.epi (rupture of the lamellar epithelium), fil.blo (filament blood vessel enlargement), foca.epi (focal hyperplasia of epithelial cells), haem.rup (hemorrhages with rupture of epithelium), ves.blo (vessel blood congestion), lift.epi (Lifting of epithelial 
cells), leuk.epi (Leukocyte infiltration of gill epithelium), lam.tel (lamellar telangiectasis), nec.sta (necrosis), others (minor changes involving hypertrophy and hyperplasia of gill epithelia).
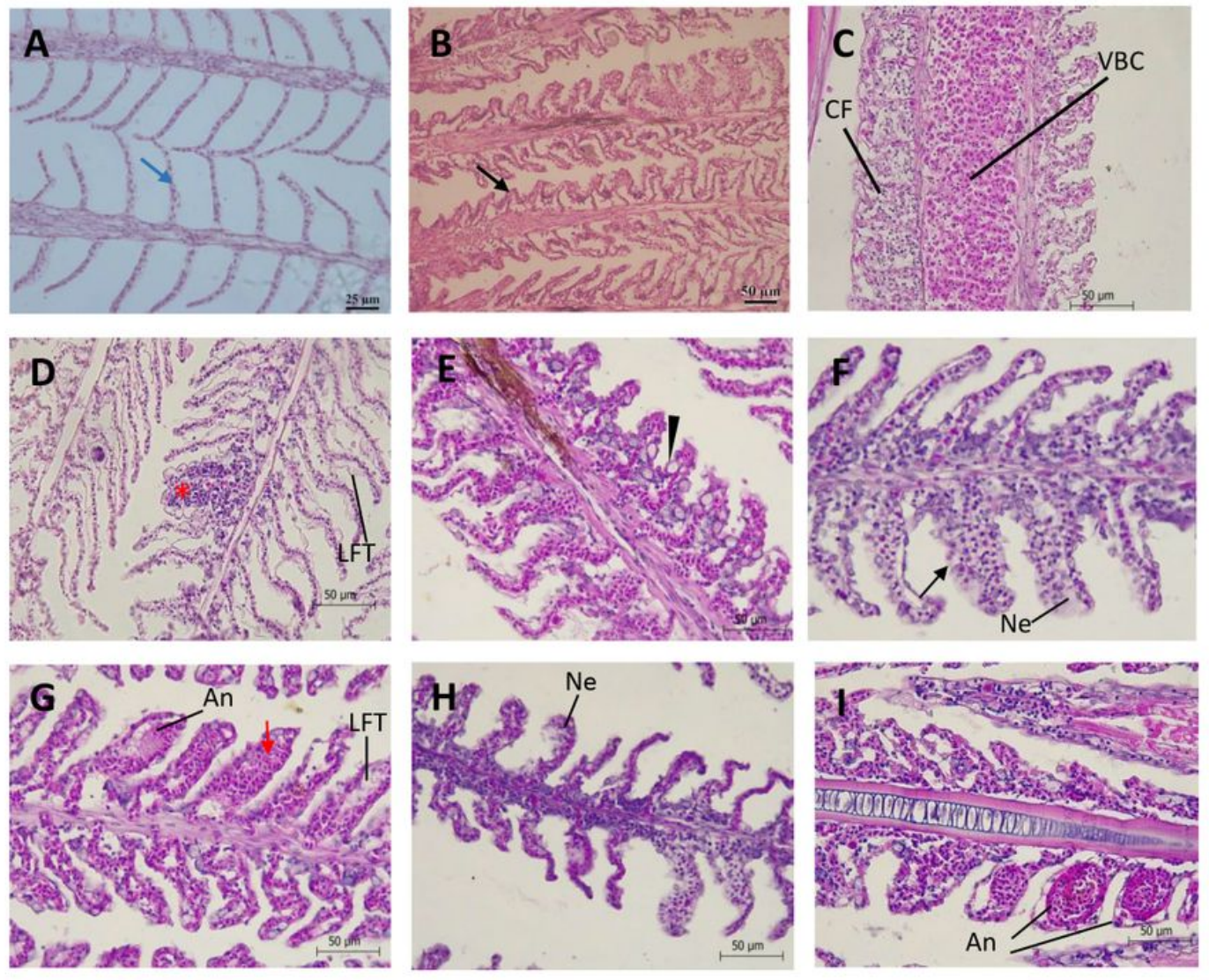

\section{Figure 8}

Histopathological gills of analyzed fish, B. ronchus (a); C. latus (d), C. undecimalis (f, h), G. stomatus (e, g, i). [a] normal structure for teleost Branchial with little lamellar derangement, filament $(F)$ and second lamella (blue arrow); [b] Fusion of several secondary lamellae (black arrow); [c] complete fusion of several lamellae (CF), vessel blood congestion (VBC); [d] Lifting of respiratory epithelial cells (LFT), focal hyperplasia of epithelial cells $\left(^{*}\right)$, [e] hypertrophy of mucus cell (head arrow) [f] epithelial rupture (arrow), necrosis ( $\mathrm{Ne}$ ), [g] aneurysm (An), hyperplasia of epithelial cells (red arrow), epithelial lifting (LFT) with some intraepithelial edema, [h] necrosis ( $\mathrm{Ne}$ ), [i] aneurysm lamellar (An), H \& E-P stain

\section{Supplementary Files}

This is a list of supplementary files associated with this preprint. Click to download. 
- GraphicalabstractPDF.pdf

Page $31 / 31$ 